\title{
Impacts of Soil Media Characteristics on Stormwater Biofiltration System Performance
}

\author{
Redahegn K. Sileshi ${ }^{1}$, Robert E. Pitt ${ }^{2}$, Shirley E. Clark $^{3}$ \\ Assistant Professor, Department of Physics, University of North Georgia, Oakwood, Georgia, USA ${ }^{1}$ \\ Emeritus Cudworth Professor of Urban Water Systems, Dept. of Civil, Construction and Environmental Engineering, \\ University of Alabama, Tuscaloosa, AL, USA ${ }^{2}$
}

Associate Professor, School of Science, Engineering and Technology, Penn State, Harrisburg, USA ${ }^{3}$

\begin{abstract}
Stormwater bioinfiltration systems can be effective options for the treatment and disposal of stormwater runoff from urban areas. However, the performance of these systems and other infiltration devices can be affected by factors such as texture, structure and degree of compaction of the treatment media. This study provides insights on media characteristics of a poorly operating biofilter facility located in Tuscaloosa, AL, along with supporting laboratory investigations. Double ring infiltrometer tests and soil compaction measurements were conducted along a large biofilter to determine the in-situ infiltration and compaction characteristics of the media. Infiltration measurements were also made during actual rain events by observing falling water levels in ponded areas. The effects of different compaction levels on the infiltration rates through the soil media were also examined during controlled laboratory column tests for comparison to the field observations. Similar tests were also conducted examining compaction effects of the media after mixing with varying amounts of filter sand to investigate restoration options. These results indicate that soil compaction results in increased bulk densities, decreased moisture capacities and has dramatic effects on the infiltration rates.
\end{abstract}

Keywords: Stormwater, bioinfiltration, infiltration, compaction

\section{INTRODUCTION}

Infiltration practices have the greatest runoff volume reduction capability of any stormwater control practice and are suitable for use in residential and other urban areas where soil infiltration rates are suitable. Many guidance manuals specify acceptable minimum infiltration rates, such as $1 \mathrm{~cm} / \mathrm{h}(0.5 \mathrm{in} / \mathrm{h})[1]$. Soil compaction that occurs in stormwater treatment facilities during construction (or improper use) can cause significant reductions in infiltration capacities of the soils. [2] noted large detrimental effects of compaction on infiltration rates in both sandy and clayey soils. Infiltration rates were reduced to near zero values in soils having even small amounts of clay, if compacted. Large reductions in the infiltration rates in sandy soils with compaction were also reported, but several centimeter per hour rates were usually still observed, even with severe compaction (down from tens of centimeters per hour if uncompacted).

The infiltration rate is the rate at which water enters the soil at the surface. The rate of infiltration depends on a number of factors, including the condition of the soil surface and its vegetative cover, the properties of the soil, such as its porosity and hydraulic conductivity, and the current moisture content of the soil [3].The infiltration rate in a soil typically decreases during periods of rainfall as the soil becomes saturated.
Vegetation in biofilters helps retain captured sediment and other pollutants, maintains infiltration capacity, decreases soil moisture through evapotranspiration, and provides some bacteriological degradation opportunities in the root zone. High bulk density is an indicator of low soil porosity and compaction [4]. Densely compacted soil causes restrictions to root growth, and poor movement of air and water through the soil. Compaction can result in shallow plant rooting and restricted plant growth, influencing crop yield and reducing vegetative cover available to protect soil from erosion. Compacted media also has adverse effects on plant growth. A bulk density value for sandy soil greater than $1.8 \mathrm{~g} / \mathrm{cm}^{3}$ restricts root growth, for example [4]

Biofilters are used in urban areas to reduce stormwater runoff volumes, peak flows, and pollutant discharges. Biofilter/Bioretention is one of the most recognized LID practices for mitigating the hydrologic impacts of urbanization development and improving water quality in urban areas [5]. These systems can reduce the volume and peak flow rates of runoff, even on sites with poorly draining soils [6]. Most of the removal benefits of biofilters devices are through physical removal as the particulate-bound pollutants are trapped in the media, and through water infiltration into the natural soil surrounding the devices. The presence of plants in these devices is common and assists in enhancing removal through many biological processes, such as described by [7] as a part of 
the extensive biofilter research conducted by Monash University.

The vegetation in biofilters slows the run-off and filters out sediment and other pollutants. The effectiveness of a biofilter is commonly reduced through clogging of the media, through short-circuiting of infiltrating water through an under-drain, or by short resident/contact times of the stormwater and the treatment media. Fig. 1 shows the typical cross-section of a stormwater biofilter device incorporating a $15 \mathrm{~cm}$ (6 in.) diameter underdrain pipe to capture the stormwater filtered through the media and return it to the surface flow regime.

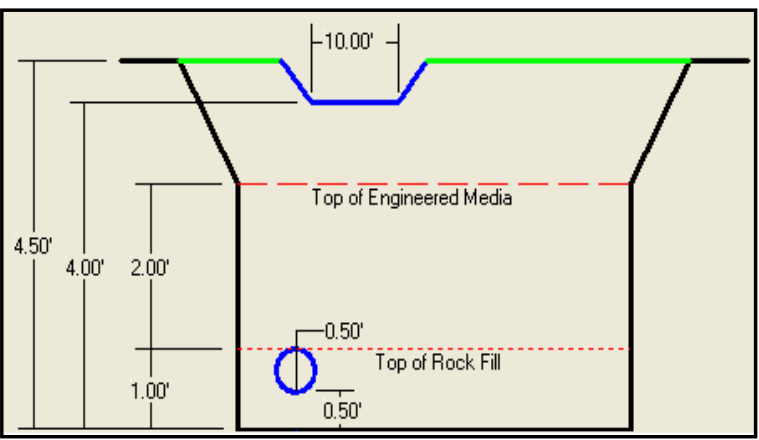

Fig. 1. Stormwater biofilter geometry schematic as modeled with WinSLAMM (Pitt and Voorhees [8]).

\section{MATERIALS AND METHOD}

Laboratory and field-scale studies were conducted to provide insight on media characteristics of a biofilter facility located in Tuscaloosa, AL. Double ring infiltrometer tests and soil compaction measurements were conducted along a large biofilter to determine the in-situ characteristics of the media.
In-situ soil density measurements were also taken at the same locations as the infiltration measurements. Infiltration measurements were also made during rain events.

The effects of different compaction levels on the infiltration rates through the soil media were also examined during controlled laboratory column tests, along with benefits associated with adding different amounts of sand and peat to the media mixture. Three levels of compaction were used to modify the density of the column media samples during the tests: hand compaction, standard proctor compaction, and modified proctor compaction. Fig. 2 shows the flow chart for this field and lab infiltration study of biofiltration facility.

\section{A. Description of Test Site}

The biofilter facility selected for this study is located in Shelby Park, Tuscaloosa, Alabama, USA adjacent to the University of Alabama's, rental car facility from which it receives stormwater flows. The biofilter is $90 \mathrm{~m}(300 \mathrm{ft})$ long and $9 \mathrm{~m}(30 \mathrm{ft})$ wide, comprising about $11 \%$ of the contributing paved and roofed source areas $(7.8 \%$ of the total drainage area, including landscaped areas). The total drainage area tributary to the biofilter was approximately 1.1 ha (2.7 acres). The drainage area and land use for the study area are shown in Table 1.

Table 1. Drainage area and land use breakdown

\begin{tabular}{cccc}
\hline Drainage area & $\begin{array}{c}\text { Area } \\
\left(\mathrm{m}^{2}\right)\end{array}$ & $\begin{array}{c}\text { Area } \\
(\mathrm{ha})\end{array}$ & $\begin{array}{c}\text { Land use } \\
(\%)\end{array}$ \\
\hline Parking & 6,062 & 0.6 & 55.6 \\
Landscaped & 3,181 & 0.3 & 29.2 \\
Roof & 1,659 & 0.2 & 15.2 \\
Total & 10,902 & 1.1 & 100 \\
\hline
\end{tabular}

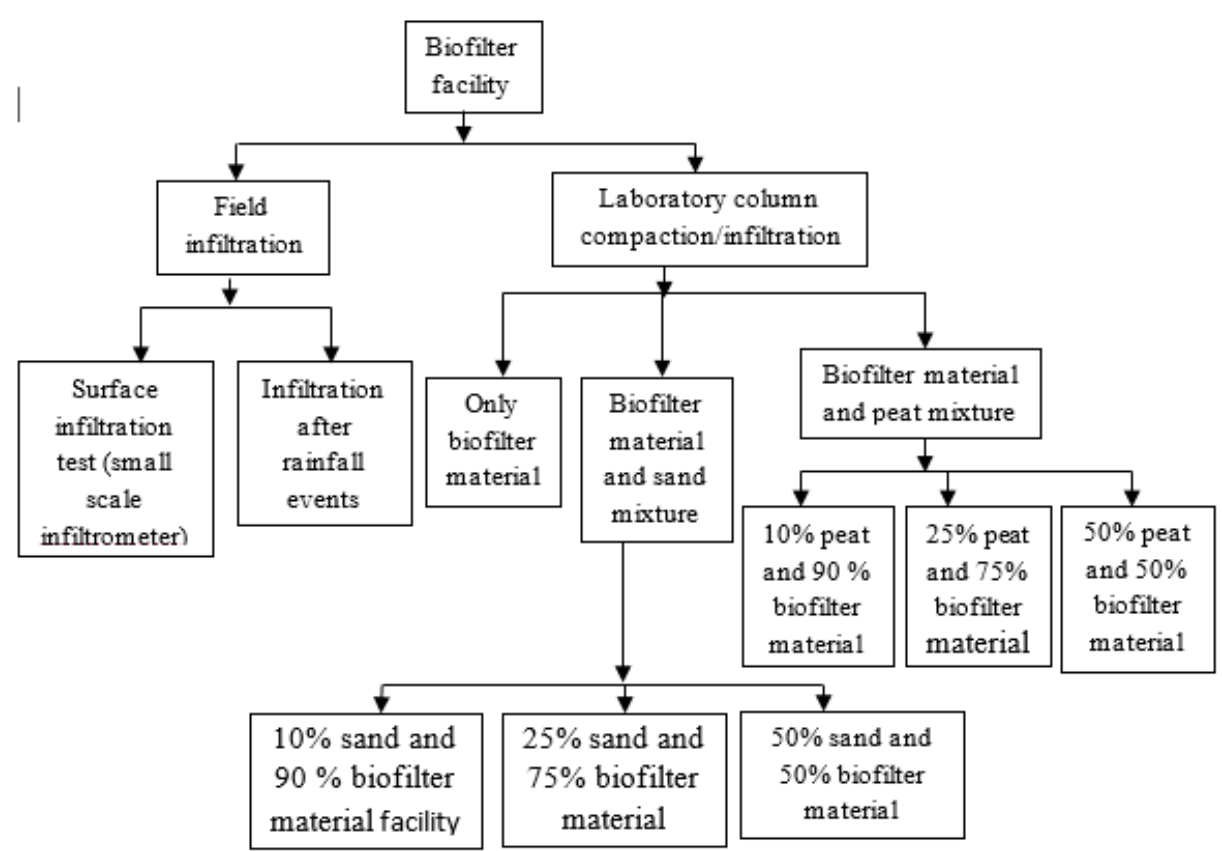

Fig. 2. Flowsheet for the field and lab infiltration study at a biofilter facility 
The biofilter receives flow from the rental car facility's parking lot, driveways, and small landscaped areas. The biofilter failed to function as well as intended soon after construction, with extended periods of standing water after rains and with poorly established vegetation. Fig.3 shows the location of the biofilter and its tributary drainage area. Since the runoff sources within the drainage area included the University fleet maintenance and rental car service area, typical runoff pollutants were expected, including sediments, bacteria, and nutrients from the landscaped areas, metals and oil and grease from the parked car areas, and zinc from the galvanized metal buildings.
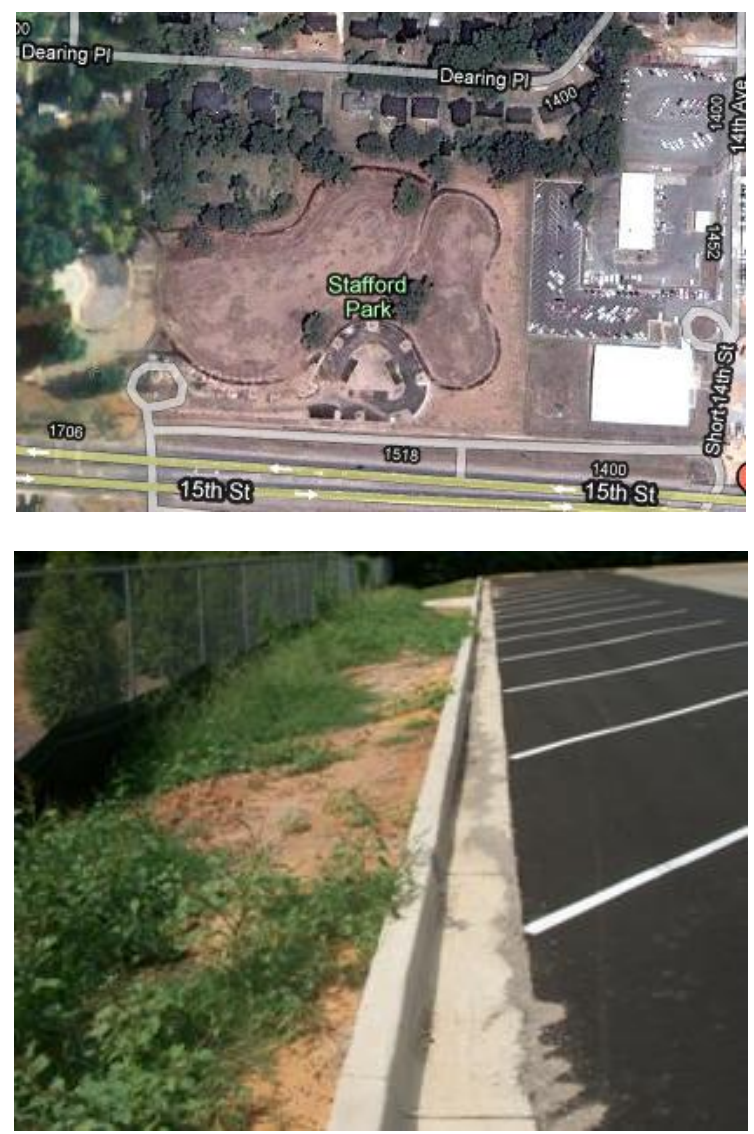

Fig. 3. Aerial photograph of biofilter location and vehicle facility tributary to the biofilter.

There was no deicing chemical use at the site as the winters in the area are generally mild with only rare snow or ice accumulations. There were no other stormwater control practices at the site, except for the large biofilter.

\section{B. Field Infiltration Study at Biofiltration Facility}

Turf-Tec Infiltrometers [9] were used to measure the infiltration rates at 12 test locations along the biofilter. These small devices have an inner chamber about $6 \mathrm{~cm}(2.5$ in.) in diameter and an outer ring about $11 \mathrm{~cm}(4.5 \mathrm{in}$.) in locations diameter.

Three infiltrometers were inserted within about $1 \mathrm{~m} \mathrm{(3}$ $\mathrm{ft}$ ) from each other to measure the variability of the infiltration rates of the soil media in close proximity, as shown in Fig. 4.

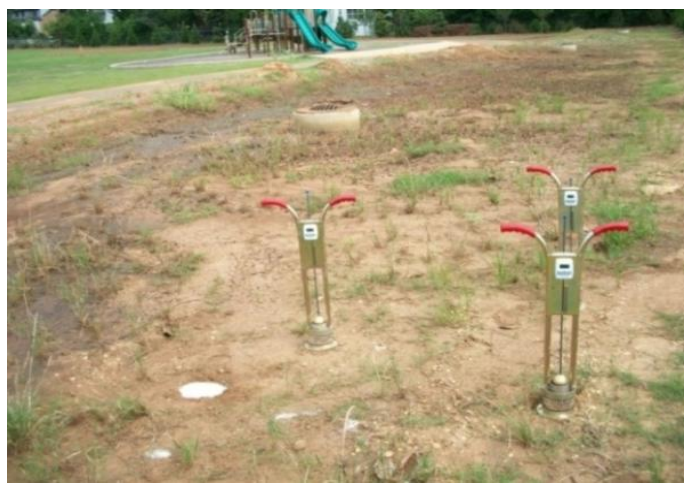

Fig. 4. Photographs showing the infiltration measurement setups at the Shelby Park biofilter

Four clusters of three infiltrometer tests were conducted along the biofilter to examine variations along the biofilter length. The infiltration measurements were taken every 5 min until the infiltration rates become constant. The infiltration rates were calculated from the rate of fall of the water level in the inner chamber of each infiltrometer over each 5 min period.

\section{Water Content and Density Measurements of the Soil Media}

In-situ soil density measurements were also taken in the same general locations as the infiltration measurements. A small hole, about $15 \mathrm{~cm}$ (6 in.) deep and $15 \mathrm{~cm}$ (6 in.) wide, was carefully hand dug to avoid disturbance of the soil. The hole's side and bottom were also carefully smoothed. All of the soil excavated from each hole was placed into Ziploc plastic bags to retain soil moisture. Sand was then poured into the hole from a graduated cylinder to measure the volume of the holes, up to the level of the soil that was removed from the test hole in the biofilter. The excavated soil media was then transported to The University of Alabama environmental lab for further analyses. The soil media was weighed moist, dried at $105^{\circ} \mathrm{C}$, and weighed again when dry for the moisture determination and to prepare the samples for further tests. The texture analyses, dry densities, moisture content (\%) of the soil media collected from each test locations were determined, as shown in Table 2.

Table 2. Soil media characteristics obtained from four locations along the biofilter.

\begin{tabular}{|c|c|c|c|c|}
\hline $\begin{array}{c}\text { Test } \\
\text { locations }\end{array}$ & $\begin{array}{c}\text { median } \\
\text { size } \\
\mathrm{D}_{50} \\
(\mathrm{~mm})\end{array}$ & $\begin{array}{l}\text { uniformity } \\
\text { coefficient } \\
\left(\mathrm{C}_{\mathrm{u}}\right)\end{array}$ & $\begin{array}{c}\text { dry } \\
\text { density } \\
\left(\mathrm{g} / \mathrm{cm}^{3}\right)\end{array}$ & $\begin{array}{c}\text { Moisture } \\
\text { content } \\
(\%)\end{array}$ \\
\hline 1 & 3.0 & 38 & 2.18 & 9.2 \\
\hline 2 & 0.5 & 17 & 2.32 & 5.6 \\
\hline 3 & 0.3 & 5.6 & 1.80 & 8.0 \\
\hline 4 & 0.7 & 12.5 & 2.05 & 8.2 \\
\hline
\end{tabular}


*uniformity coefficient (the ratio of the $60^{\text {th }}$ to the $10^{\text {th }}$ percentile particle sizes)

The soil texture was determined by sieve analyses(ASTM standard D6913-04), and compaction conditions were measured in the lab. Three methods were used to modify the compaction of the biofilter soil for additional laboratory column infiltration tests: hand compaction, standard proctor compaction, and modified proctor compaction. Both standard and modified proctor compactions follow ASTM standard D1140-54. The biofilter media was classified as sandy clay loam, with $20 \%$ clay and $80 \%$ sand (3\% organic matter content). According to the UA laboratory tests, the median size of the samples ranged from 300 to $3,000 \mu \mathrm{m}$, and in-situ density measurements indicated surface dry density values of about $2 \mathrm{~g} / \mathrm{cc}$ (greater than the critical $1.8 \mathrm{~g} / \mathrm{cm}^{3}$ value [4] that affects plant growth), corresponding to severely compacted conditions (close to "modified" compaction conditions for this media). There was very little "bio" in the Shelby Park biofilter facility, as shown on Fig. 4, indicating compacted media having adverse effects on the plant growth.

\section{Biofilter Plant Nutrients}

Plants can contribute to treatment efficiency in biofilters both directly, through plant uptake and maintenance of soil porosity and moisture reductions, as well as indirectly, through influence on soil microbial communities $[10,11,12,13]$.Variations in pollutant removal (including metals) among plant species were noted, but is generally small [10,14]. The selection of vegetation for biofilters should not be based solely on their pollutant removal abilities, but also on their ability to survive in potentially stressful growth conditions, such as drought periods and periodically inundation [15]. Soil chemical tests indicate whether a nutrient level in the soil is low, medium (moderate) or high (adequate). The nutrient rating depends on the soil group and the crop. Samples of the biofilter media were analyzed by the soils laboratory at Auburn University for selected nutrients and other basic characteristics. The summary of the soil test details is shown in Table 3.

Table 3. Nutrient report summary.

\begin{tabular}{lc}
\hline Nutrient & Percent \\
\hline $\mathrm{pH}$ & 6.8 \\
Cation Exchange capacity (CEC) & \\
(meq/100g) & 4 \\
Organic matter (OM) & 3.1 \\
Sodium Adsorption ratio (SAR) & 0.3 \\
\hline
\end{tabular}

Organic matter (OM) improves soil structure and soil tilth, and helps to provide a favorable medium for plant growth. Soils with large amounts of clay generally require large amounts of organic matter. Generally, healthy soil has between 3 and 5\% organic material. The organic matter content of the biofilter soil is $3.1 \%$ indicating that it is favorable for plant growth. The cation exchange capacity (CEC) of a soil is a measurement of its ability to bind or hold exchangeable cations. The biofilter soil had a CEC value $4.0 \mathrm{meq} / 100 \mathrm{~g}$ and a $\mathrm{pH}$ value of 6.8. Typically CEC values, as defined by the Auburn University Soil Testing Laboratory [16], vary from soil to soil, with sandy soils generally having CEC values ranging from 0 to 4.6 and loam soils having CEC values ranging from 4.6 to 9 . According to the Alabama Cooperative Extension System, the ideal soil $\mathrm{pH}$ value for most crops ranges between 5.8 and 6.5 and for acid loving plants ranges between 5.0 and 5.7.

The Sodium Adsorption Ratio (SAR) of a soil is an index for characterizing soil sodicity, which describes the proportion of sodium to calcium and magnesium in the soil solution [17]. SAR has been documented to be causing premature failures of biofilters in northern communities where snowmelt sodium increases the SAR above critical values [18].

These failures occur when snowmelt water is allowed to enter a biofilter that has clay in the soil mixture. The largest problem is associated with curb-cut biofilters or parking lot biofilters in areas with snowmelt entering these devices, especially if clay is present in the engineered backfill soil [18]. When the SAR rises above 12 to 15 , serious physical soil problems arise and plants have difficulty absorbing water [19]. The Shelby Park biofilter soil had a SAR value 0.3 and was not a problem, and it would be rare for high sodium content runoff to enter the biofilter. The soil chemical/fertility measurements did not indicate any problems with plant growth, so the poor plant activity was associated with drought, long periods of saturated soils, and/or soil compaction.

\section{E. Biofilter Surface Ponding}

Water will pond on the surface of the biofilter if the runoff rate entering the biofilter facility is greater than the infiltration capacity of the material in the biofilteror and the underlying native soil. Biofilters are designed with surface ponding storage to hold runoff during short periods of intensive rainfall for later infiltration. In most cases, design guidance restricts ponding to relatively short periods after rains (such as 24 to $72 \mathrm{~h}$ ) to minimize nuisance insect problems. Extended periods of surface ponding (several days) of water on the Shelby Park biofilter was often observed following heavy rainfall events (Fig.5) indicating that the media or underlying soil had infiltration rates that were too restrictive (little flow was observed in the underdrains).

Infiltration rate measurements were manually recorded in the biofilter ponded areas after five rain events between July 2010 and April 2011. Depth indicator scales were placed at 3 to 5 different locations in the biofilter in the ponded areas and measured every $30 \mathrm{~min}$. 


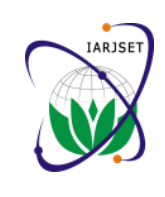

IARJSET

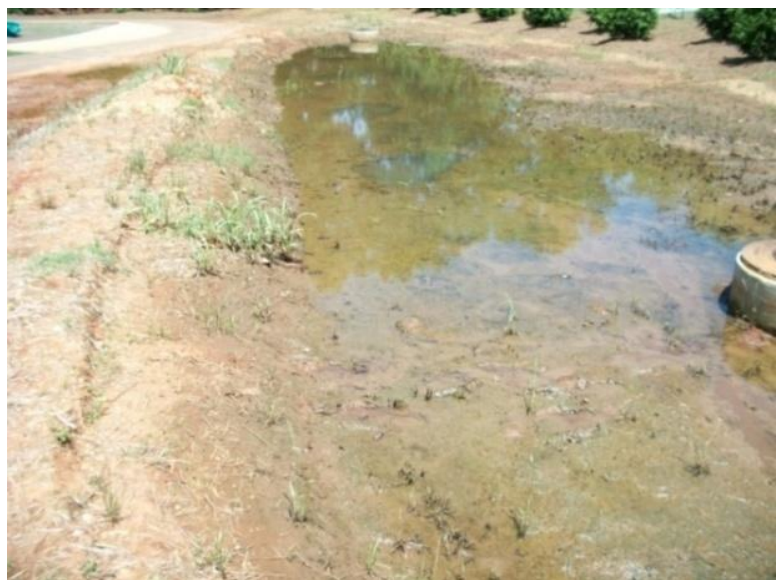

Fig. 5. Ponded water on the biofilter surface observed after rainfall (the vegetation cover is very poor indicating likely serious compaction).

at the beginning of the observation period for each event, and less frequently as the observations progressed, until the water completely infiltrated. The changes in water level and elapsed times were recorded since the beginning of the first measurement. Measurements were taken only during the daylight hours and it was therefore difficult to accurately predict the total drainage time for some events that were dry by the following morning. This method is time consuming, labor intensive, and greatly depends on operator care for accuracy, but was needed to verify the infiltrometer measurements using the Turf-Tec units during dry weather. These in-situ infiltration measurements were taken after the runoff ceased and the biofilter was fully saturated, corresponding to the Fc rates (final, constant, or saturated rates) which are also the most important rates used for design and analysis of biofilters.

\section{F. Laboratory Column Tests}

A series of $100 \mathrm{~mm}$ (4 in.) diameter PVC pipes $0.9 \mathrm{~m} \mathrm{(3}$ ft) long, purchased from a local building supply store in Tuscaloosa, AL, were used for these tests as shown in Fig. 6.

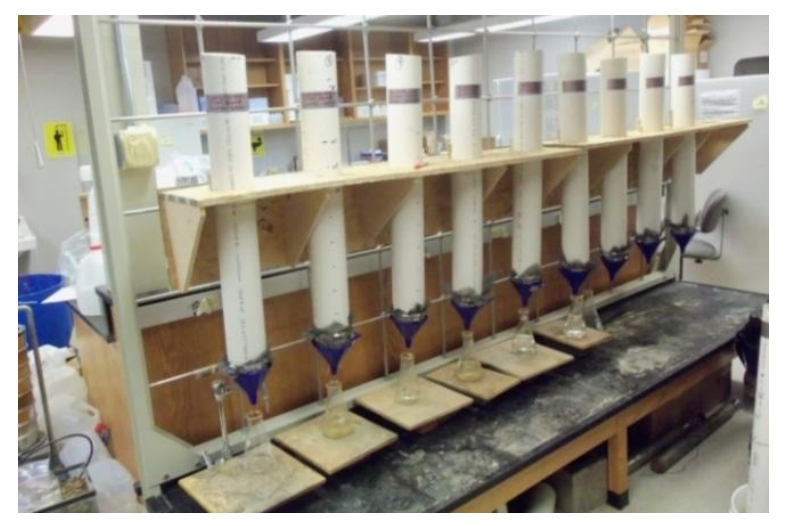

Fig.6. Laboratory column setup.

The bottom of the columns had a fiberglass window screen (about $1 \mathrm{~mm}$ openings) secured to contain the media and were placed in funnels. The columns were filled with about $5 \mathrm{~cm}$ (2 in.) of cleaned pea gravel purchased from a local supplier. The columns had various mixtures of media, filter sand, and peat added on top of the gravel layer and subjected to varying amounts of compaction. The filter sand was purchased from a local supplier in Tuscaloosa, Alabama. It has a median particle size $\left(D_{50}\right)$ of about $0.7 \mathrm{~mm}$ and a uniformity coefficient $\left(\mathrm{C}_{\mathrm{u}}\right)$ of 3 . To separate the gravel layer from the media layer, the coarse fiberglass window screen was placed over the gravel layer and then filled with the soil media brought from the biofilter, with varying amounts of well-mixed filter sand added (biofilter media alone; $10 \%$ sand and $90 \%$ biofilter soil; $25 \%$ sand and $75 \%$ biofilter soil; $50 \%$ sand and $50 \%$ biofilter soil) well mixed with the biofilter media. The media/sand layer was about $0.46 \mathrm{~m}(1.5 \mathrm{ft})$ thick.

Three levels of compaction were used to modify the density of the column media/sand samples during the tests: hand compaction, standard proctor compaction, and modified proctor compaction. Both standard and modified proctor compactions follow ASTM standard D1140-54. The standard proctor compaction hammer is $24.4 \mathrm{kN}$ and has a drop height of $300 \mathrm{~mm}$ (12 in). The modified proctor hammer is $44.5 \mathrm{kN}$ and has a drop height of $460 \mathrm{~mm}$ (18 in). For the standard proctor setup, the hammer is dropped on the test soil 25 times on each of three soil layers, while for the modified proctor test, the heavier hammer was also dropped 25 times, but on each of five soil layers. The modified proctor test therefore results in much more compacted soil, and usually reflects the most compacted soil observed in the field. The hand compaction is done by gently hand pressing the media/sand material to place it into the test cylinder with as little compaction as possible, with no voids or channels. The hand compacted soil specimens therefore have the least amount of compaction. The densities were directly determined by measuring the weights and volume of the media/sand material added to each column.

The infiltration rates through the biofilter media/sand mixtures were measured in each column using municipal tap water. The surface ponding depths in the columns ranged from $28 \mathrm{~cm}$ (11in.) to $36 \mathrm{~cm} \mathrm{(14} \mathrm{in),}$ corresponding to the approximate maximum ponding depth at the Shelby Park biofilter. The freeboard depth above the maximum water levelto the top of the columns was about $5 \mathrm{~cm}$ ( $2 \mathrm{in}$.) to $7.5 \mathrm{~cm}$ (3 in.). Infiltration rates in the media mixtures were determined by measuring the rates with time until apparent steady state rates were observed. The laboratory column setup for the infiltration measurements in the different media is shown in Fig. 6.

\section{RESULTS AND DISCUSSION}

\section{G. In-Situ Biofilter Infiltration Measurements}

The small-scale double-ring infiltrometer tests (comprised of three separate setups each) conducted 
along the biofilter to examine variations in infiltration rates indicated that the average final infiltration rates and the coefficients of variation averaged $14.5 \mathrm{~cm} / \mathrm{h}(5.7$ in./h) and 0.5 respectively, and ranged from $4.3 \mathrm{~cm} / \mathrm{h}$ $(1.7 \mathrm{in} . / \mathrm{h})$ to $25.5 \mathrm{~cm} / \mathrm{h}(10 \mathrm{in} . / \mathrm{h})$ for the 12 separate tests. In contrast, the measurements of the infiltration rates of the ponded water after actual rains indicated average saturated infiltration rates of only about $1 \mathrm{~cm} / \mathrm{h}(0.45$ in./h) and coefficients of variation about 0.7 . The actual rain event ponded average infiltration rates were only about $25 \%$ of the lowest infiltrometer measurements observed during the small scale tests, indicating a shortcoming of the small devices. The actual event measurements were obtained with fully saturated conditions of the complete biofilter, while the small scale tests were only affected by saturated conditions in close proximities to the test locations. It is expected that the fully saturated conditions had a greater negative effect on the infiltration rates than the locally saturated conditions. Also, it is possible that the compaction of the biofilter media extended to the bottom of the excavated trench, with increasing compaction with depth due to the media placement methods. Table 4 shows the infiltration rate measurements from the biofilter ponded areas after five rainfall events.

Table 4. Infiltration measurement at ponded locations in biofilter.

\begin{tabular}{ll}
\hline Event Date & $\mathrm{f}_{\mathrm{c}}(\mathrm{cm} / \mathrm{h}, \mathrm{COV})$ \\
\hline 27-Jul-10 & $1.6(0.47)$ \\
23-Nov-10 & $1.1(0.68)$ \\
Feb 5-6,11 & $0.24(0.63)$ \\
9-Mar-11 & $0.6(0.74)$ \\
16-Apr-11 & $1.1(0.4)$ \\
\hline
\end{tabular}

The relationships between specifications of the treatment media and recommended infiltration rates and biofilter sizing and performance are not very well quantified or discussed in many of the state guidelines reviewed [20].

Most states set complete surface biofilter draindown times of 24 to 72 hours to avoid standing water and potential mosquito larval habitat. If the maximum surface ponding depth is $30 \mathrm{~cm}(1 \mathrm{ft})$, this corresponds to a minimum infiltration rate of about 0.4 to $1.3 \mathrm{~cm} / \mathrm{h}$. The influence of an underdrain or highly pervious underlying soils is also critical and will often dictate design and performance of biofilters. Extended periods of surface ponding (more than 72 hours) of water in the Shelby Park biofilter were often observed following large rainfall events which resulted in maximum ponded water depths. Media compaction is likely the major problem associated with poor infiltration rates and poor plant growth at the Shelby Park biofilter facility, as the media chemical analyses did not indicate any soil fertility problems. Variations of final infiltration rates (about a factor of 2) were also observed in the small infiltrometers that were inserted within about a meter from each other at each test location along the biofilter, as shown in Fig. 7. The small-scale surface infiltration measurements did not include sufficient water to saturate the system and only indicated more favorable surface conditions. Therefore, care needs to be taken when using any surface infiltration method when evaluating an infiltration facility having deeply placed media or excavations.

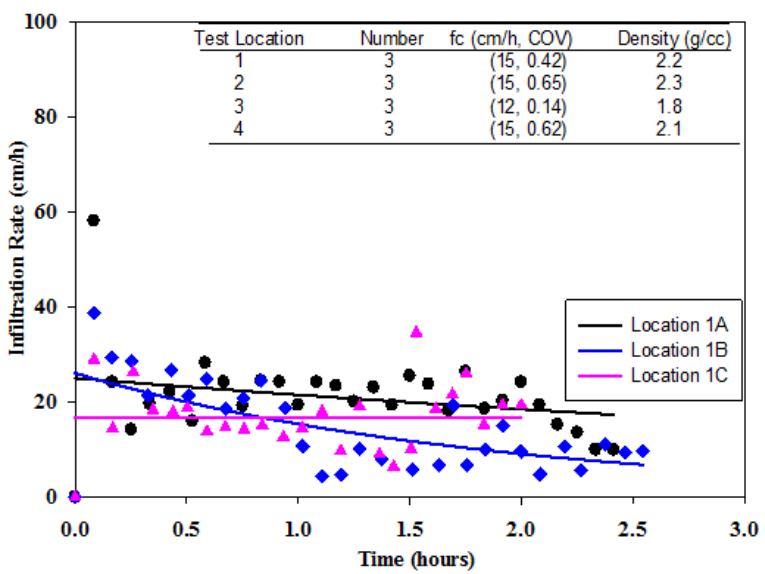

Fig. 7. Example biofilter surface small-scale infiltration measurements fitted with the Horton equation.

A trench or borehole infiltration test would be more reliable in this case, or more preferred in-situ measurements with pressure transducer recording depth sensors during actual rains.

\section{H. Laboratory Infiltration Results}

Biofilter media obtained from the surface of the biofilter was brought to the laboratory for extended column testing. Fig. 8 shows box and whisker plots of the infiltration rates for different test conditions, comparing different compactions with varying amounts of sand amendments. The box and whisker plots indicate the major benefits by adding sand to the media material, even at only $10 \%$ for the most severely compacted material (the infiltration rates increased from about 0.8 $\mathrm{cm} / \mathrm{h}(0.3 \mathrm{in} . / \mathrm{h})$ to $3.1 \mathrm{~cm} / \mathrm{h}(1.2 \mathrm{in} . / \mathrm{h}))$.

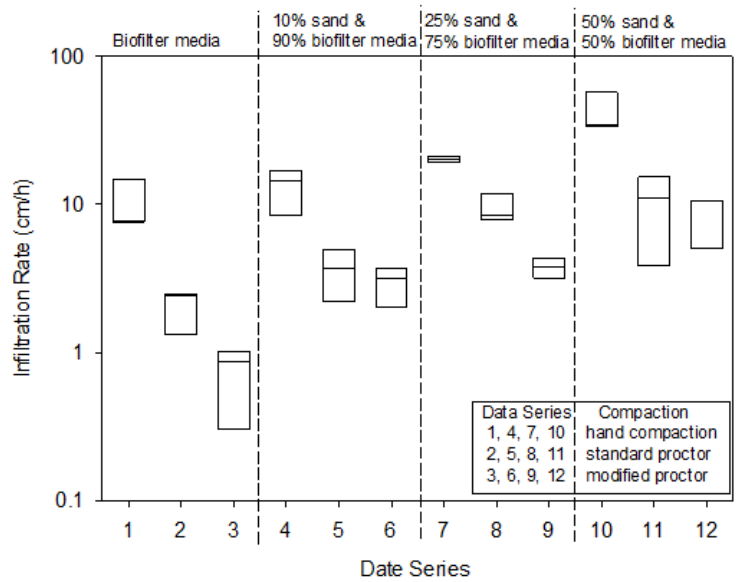

Fig. 8. Box and whisker plots of the different test conditions, comparing different compaction conditions 
with varying amounts of sand amendments (hand, standard proctor, and modified proctor compaction for each amendment condition). measurements fitted with the Horton equation. Table 5 summarizes the column test results for the biofilter soil alone and with varying amounts of added sand, and for

Table 5. Lab Column Saturated Infiltration Measurements.

\begin{tabular}{|c|c|c|c|c|c|c|}
\hline $\begin{array}{c}\text { Compaction } \\
\text { method }\end{array}$ & Test & $\begin{array}{l}\text { Number of } \\
\text { column tests }\end{array}$ & $\begin{array}{c}\text { biofilter } \\
\text { media only }\end{array}$ & $\begin{array}{c}10 \% \text { sand \& } \\
90 \% \text { biofilter } \\
\text { media }\end{array}$ & $\begin{array}{c}25 \% \text { sand and } \\
75 \% \text { biofilter } \\
\text { media }\end{array}$ & $\begin{array}{c}50 \% \text { sand and } \\
50 \% \text { biofilter } \\
\text { media }\end{array}$ \\
\hline & & & \multicolumn{4}{|c|}{$\mathrm{f}_{\mathrm{c}}(\mathrm{cm} / \mathrm{h}$, density $(\mathrm{g} / \mathrm{cc}))$} \\
\hline hand & $\begin{array}{l}\text { mean } \\
\text { COV }\end{array}$ & 3 & $\begin{array}{c}10.2(1.54) \\
0.43\end{array}$ & $\begin{array}{l}13.2 \\
0.33\end{array}$ & $\begin{array}{c}20.1(1.52) \\
0.05\end{array}$ & $\begin{array}{c}41.7(1.63) \\
0.32\end{array}$ \\
\hline standard & $\begin{array}{l}\text { mean } \\
\mathrm{COV}\end{array}$ & 3 & $\begin{array}{c}2.1(1.66) \\
0.31\end{array}$ & $\begin{array}{c}3.6 \\
0.38\end{array}$ & $\begin{array}{c}9.4(1.71) \\
0.23\end{array}$ & $\begin{array}{c}10.1(1.70) \\
0.57 \\
\end{array}$ \\
\hline modified & $\begin{array}{l}\text { mean } \\
\mathrm{COV}\end{array}$ & 3 & $\begin{array}{c}0.73(1.94) \\
0.51\end{array}$ & $\begin{array}{l}3.0 \\
0.3\end{array}$ & $\begin{array}{c}3.8(1.76) \\
0.15\end{array}$ & $\begin{array}{c}6.8(1.77) \\
0.46\end{array}$ \\
\hline
\end{tabular}
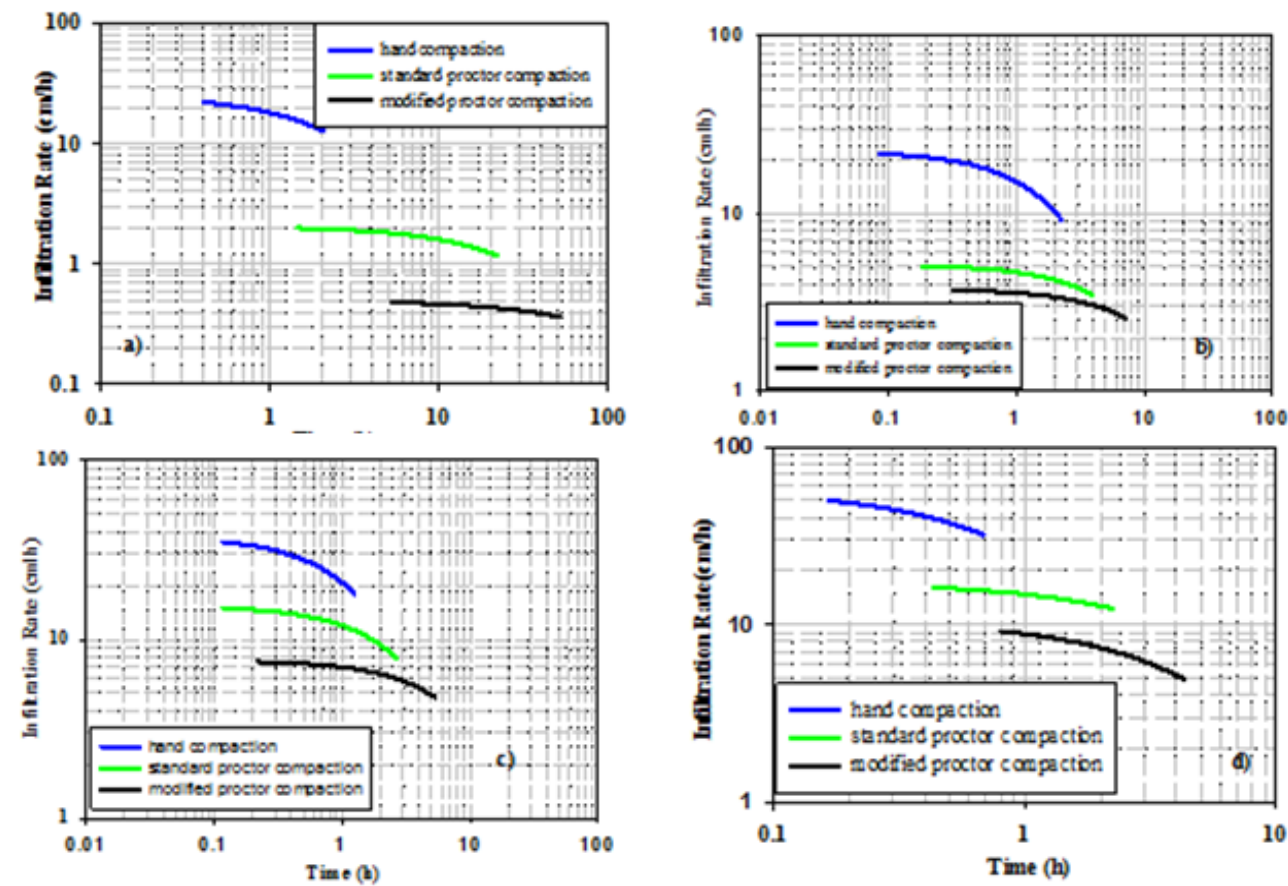

Fig. 9. Example laboratory infiltration measurements fitted with Horton equations, a) biofilter soil, b) $10 \%$ sand and $90 \%$ biofilter soil mixture, c) $25 \%$ sand and $75 \%$ biofilter soil mixture, d) $50 \%$ sand and $50 \%$ biofilter soil mixture.

Smaller benefits were observed for the less-compacted conditions; at least until $50 \%$ sand was added. It is seen that the benefits of decreased compaction were much greater than the sand addition benefits. However, added sand prevented this media material from having greatly reduced rates, even with severe compaction (averaging about $0.8 \mathrm{~cm} / \mathrm{h}(0.3 \mathrm{in} . / \mathrm{h}$ without sand $)$, the infiltration rates increased to about $6.9 \mathrm{~cm} / \mathrm{h}(2.7 \mathrm{in} . / \mathrm{h})$ with $50 \%$ sand. During the laboratory tests, the average final infiltration rates through the biofilter soil only with increasing degrees of compaction were $10.2 \mathrm{~cm} / \mathrm{h}$ (4 in. $/ \mathrm{h}), 2 \mathrm{~cm} / \mathrm{h}(0.8 \mathrm{in} . / \mathrm{h})$, and $0.8 \mathrm{~cm} / \mathrm{h}(0.3 \mathrm{in} . / \mathrm{h}) \mathrm{using}$ hand compaction, standard proctor compaction and modified proctor compaction methods, respectively. The final infiltration rates of the hand compacted biofilter soil were reduced by 80 and $93 \%$ using the standard proctor compaction and modified proctor compaction methods, respectively. Fig. 9 shows example laboratory infiltration
Table 6 summarizes the column test results for the biofilter soil alone and with varying amounts of wellmixed peat added, using the standard proctor compaction method.

Table 6. Laboratory infiltration tests using biofilter soil and peat for standard proctor compaction method.

\begin{tabular}{cccc}
\hline Mixture & Number & $\begin{array}{c}\mathrm{f}_{\mathrm{c}} \\
(\mathrm{cm} / \mathrm{h}, \\
\mathrm{COV})\end{array}$ & $\begin{array}{c}\text { Density } \\
(\mathrm{g} / \mathrm{cc})\end{array}$ \\
\hline 10\% peat and & & 5.4 & \\
$90 \%$ biofilter soil & 3 & $(0.26)$ & 1.64 \\
25\% peat and & & 5.8 & \\
$75 \%$ biofilter soil & 3 & $(0.18)$ & 1.52 \\
$50 \%$ peat and & & 9.1 & \\
$50 \%$ biofilter soil & 3 & $(0.43)$ & 1.23 \\
\hline
\end{tabular}


Vol. 4, Issue 3, March 2017

The average final infiltration rate increased from $5.4 \mathrm{~cm} / \mathrm{h}$ $(2.1 \mathrm{in} . / \mathrm{h})$ to $9.1 \mathrm{~cm} / \mathrm{h}(3.6 \mathrm{in} . / \mathrm{h}$ ) as the peat content increased from 10 to $50 \%$. This indicated an average increase of $40 \%$ in the infiltration rate. The peat amendment test indicated that the infiltration rates through the mixtures were extremely high for hand compaction conditions and they were very low for modified proctor compaction conditions, and as a result, no flow measurements were possible for those extreme conditions. Heavy compaction compressed the peat additions and effectively resulted in zero infiltration rates.

\section{Statistical Analyses}

Statistical analyses were conducted to determine the effects of sand and compaction, plus their interactions, on the infiltration rates through various mixtures of sand and biofilter media. A complete factorial experiment [21] having two level and 2 factors $\left(2^{2}\right)$ with varying sand and compaction conditionswas used to examine the effects of those factors, plus their interaction, on the infiltration rates. The factors studied, and their low $(-1)$ and high values (+1) used in the calculations, are shown in Table 7.

Table 7. Experimental factors and their levels for full $2^{2}$ factorial experiment.

\begin{tabular}{lcc}
\hline Variable & $\begin{array}{c}\text { Low value } \\
(-1)\end{array}$ & $\begin{array}{c}\text { High value } \\
(+1)\end{array}$ \\
\hline $\begin{array}{l}\text { Percentage of sand in the mixture } \\
(\mathrm{S}), \%\end{array}$ & 10 & 50 \\
$\begin{array}{l}\text { Compaction level }(\mathrm{C}), \\
\text { hand/modified proctor }\end{array}$ & hand & $\begin{array}{c}\text { modified } \\
\text { proctor }\end{array}$ \\
\hline
\end{tabular}

Data analyses were performed using the statistical software package Minitab (version 16). Normal plots of the standardized effects, residual plots, main effects plots, and interaction plots were prepared to examine the effects of the factors and to compare the significance of each effect. An analysis of variance (ANOVA) table was constructed to determine the significant factors and their interactions needed to best predict media infiltration rates. Statistical hypothesis tests using a p-value of 0.05 (95\% confidence) were used to determine whether the observed data were significantly different statistically from the null hypothesis. Normal probability plots of effects and standard error from replicates are used to identify significant factors and compare the relative magnitudes and the statistical significance of both main and interaction effects, but the results were not visually clear (likely due to few data and few factors). ANOVA test were conducted to identify possible significant factors. The results of the factorial analyses are summarized in Table 8 .

Table 8. Table of contrasts showing the results of the effects and half-effects.

\begin{tabular}{ccccccc}
\hline Case & $\mathrm{S}$ & $\mathrm{C}$ & $\mathrm{SC}$ & $\begin{array}{c}\mathrm{F}_{\mathrm{c}} \\
(\mathrm{cm} / \mathrm{h})\end{array}$ & ID & $\begin{array}{c}\text { effects/ } \\
\mathrm{SE}\end{array}$ \\
\hline 1 & + & + & + & 6.8 & average & 5.7 \\
2 & + & - & - & 41.7 & $\mathrm{~S}$ & 2.9
\end{tabular}

\begin{tabular}{|c|c|c|c|c|c|c|}
\hline $\begin{array}{l}3 \\
4\end{array}$ & - & + & $\begin{array}{l}- \\
+\end{array}$ & $\begin{array}{c}3 \\
13.2\end{array}$ & $\begin{array}{c}\mathrm{C} \\
\mathrm{SC}\end{array}$ & $\begin{array}{c}-4 \\
-2.2\end{array}$ \\
\hline & & & (grand) & 16.2 & & \\
\hline $\begin{array}{l}\text { Avg. } \\
F @-1\end{array}$ & 8.1 & 28 & 22.3 & & & \\
\hline $\begin{array}{l}\text { Avg. } \\
F @+1\end{array}$ & 24 & 4.9 & 10 & & & \\
\hline$\Delta$ & 16 & 23 & -12.3 & & & \\
\hline$\Delta / 2$ & 8.1 & 11 & -6.2 & & & \\
\hline
\end{tabular}

Note: S: \% sand and C: compaction

An ANOVA test was also used to test the significance of the regression coefficients, which highly depends on the number of data observations (Table 9).

Table 9. Analysis of variance for Fc $(\mathrm{cm} / \mathrm{h})$ (coded units).

\begin{tabular}{lrrrrrr}
\hline & D & \multicolumn{1}{c}{ Seq } & \multicolumn{1}{c}{ Adj } & Adj & & \\
Source & F & \multicolumn{1}{c}{ SS } & \multicolumn{1}{c}{ SS } & MS & F & P \\
\hline Main & & 241 & 241 & 120 & 2 & 0.00 \\
Effects & 2 & 6 & 6 & 8 & 5 & 0 \\
& & & & & 1 & 0.00 \\
\multicolumn{1}{c}{ S } & 1 & 595 & 595 & 595 & 2 & 8 \\
& & 182 & 182 & 182 & 3 & 0.00 \\
$\quad$ C & 1 & 1 & 1 & 1 & 7 & 0 \\
2-Way & & & & & & \\
Interactions & & & & & 1 & 0.00 \\
& 1 & 619 & 619 & 619 & 3 & 8 \\
$\quad$ S*C & 1 & 619 & 619 & 619 & 3 & 8 \\
Residual & & & & & & \\
Error & 8 & 394 & 394 & 49 & & \\
Pure Error & 8 & 394 & 394 & 49 & & \\
Total & 11 & 342 & & & & \\
\hline Not: S: $\%$ & 8 & & & & \\
\hline
\end{tabular}

Note: S: \% sand and C: compaction

When only a few data observations are available, strong and important relationships may not be shown to be significant, or high $\mathrm{R}^{2}$ values could occur with insignificant equation coefficients. These data were evaluated using the p-value (the probability of obtaining a test statistic that is at least as extreme as the calculated value if there is actually no difference; the null hypothesis is true) calculated during the ANOVA tests. The independent variable was used to predict the dependent variable when $\mathrm{p}<0.05$. Mixture compactions seem to have higher effects on the infiltration rates than percent sand and their interactions.

\section{J. Model Fitting}

The effects and half-effects of the significant factors (main effects and interactions) were used to predict the infiltration rate performance of various mixtures. Table 10 is a table of contrasts and shows the results of the effects and half-effect of the factors (sand and compaction) and their interactions. As noted previously, the significant factors and interactions that affect the 
responses are percent sand, compaction, and their interactions. Those factors and interactions have to be included in the prediction equation. These factors have significant effects ( $p$-values less than the chosen value of $\alpha=0.05)$ on the infiltration rates and a model was created wherein these factors are included. The prediction Equation 1 can be written in terms of the grand mean and half-effects, excluding the nonsignificant factors:

$$
\hat{f}=\overline{\bar{f}}+\left(\frac{\Delta S}{2}\right) S+\left(\frac{\Delta C}{2}\right) C+\left(\frac{\Delta S C}{2}\right) S C
$$

where:

$$
\begin{aligned}
& \hat{f}=\text { predicted response }(\mathrm{F} \text { pred }), \mathrm{cm} / \mathrm{h} \\
& \overline{\bar{f}}=\text { grand mean }(\mathrm{F} \text { grand }), \mathrm{cm} / \mathrm{h} \\
& \frac{\Delta}{2}=\text { half-effects of each factor or } \\
& \text { interaction } \\
& \mathrm{S}=\text { effects of sand }(\%)
\end{aligned}
$$

$\mathrm{C}=$ effects of compaction

The final prediction Equation 2 is given as: sand mixture ranged from 3 to $42 \mathrm{~cm} / \mathrm{h}$. Fig. 10 shows a scatterplot of the observed vs. fitted Fc values, indicating very good fits of the observed with the predicted Fc values over a wide range of conditions.

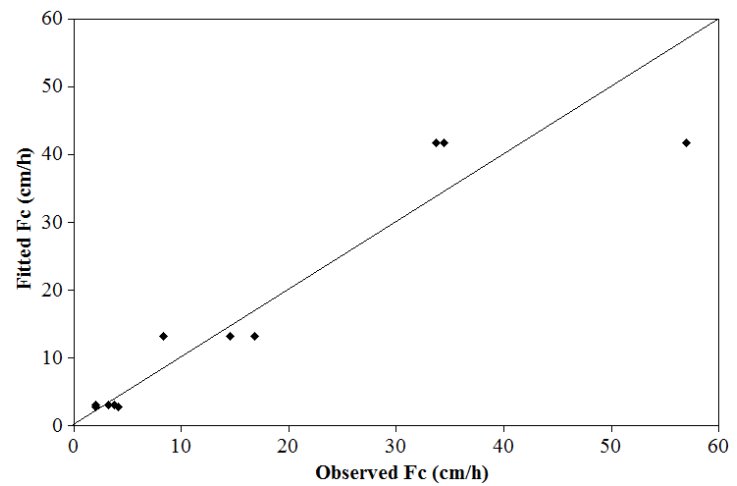

\begin{tabular}{|c|c|c|c|c|c|c|}
\hline Parameter & Avg. value & Equation & $\mathrm{S}(50 \%=+/ 10 \%=-)$ & $\begin{array}{c}\mathrm{C}(\text { hand }=- \\
/ \text { modified } \\
\text { proctor }=+)\end{array}$ & $\mathrm{SxC}$ & $\begin{array}{c}\text { Model } \\
\text { value }\end{array}$ \\
\hline & & & + & + & + & 6.8 \\
\hline \multirow[t]{2}{*}{$f(\mathrm{~cm} / \mathrm{h})$} & 16.2 & \multirow{2}{*}{$\begin{array}{l}f=16.2 \pm(8.1 \mathrm{~S}) \pm \\
(-1.1 \mathrm{C}) \pm(-6.2 \mathrm{SC})\end{array}$} & + & - & - & 41.7 \\
\hline & & & - & + & - & 3 \\
\hline
\end{tabular}

Fig.10. Scatterplot of observed vs. fitted Fc values

Residual analyses were conducted to investigate the goodness of model fit (Fig. 11).

$$
\hat{f}=16.2+8.1 S-11.2 C-6.2 S C \quad 2
$$

Table 10 shows example calculations how the above equation can be used.

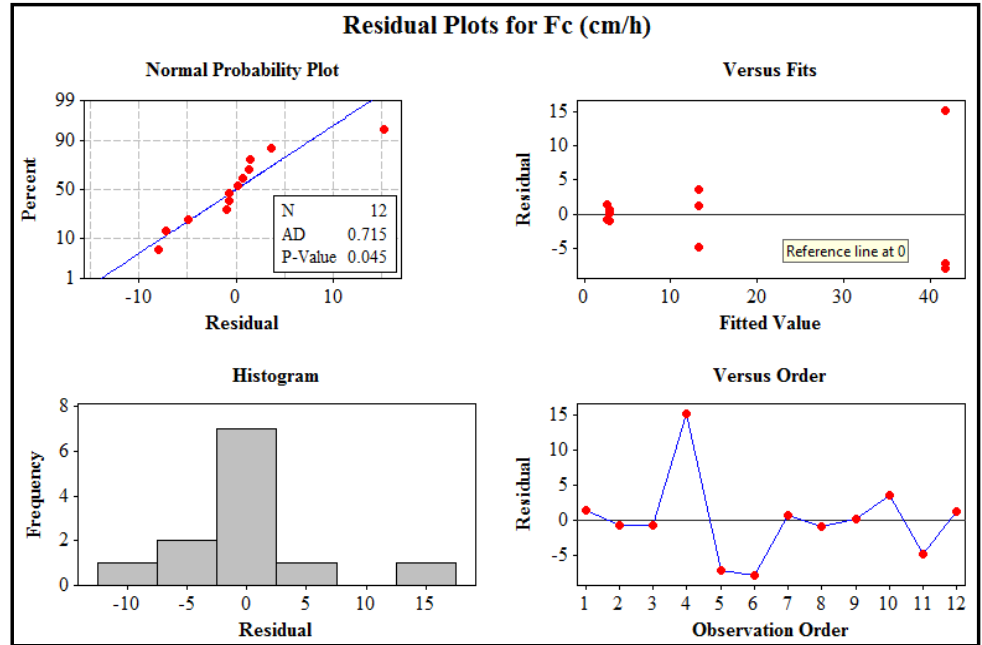

Fig 11. Residuals analysis plot

The measured values during the laboratory tests ranged from 2 to $57 \mathrm{~cm} / \mathrm{h}$. The highest infiltration rates were noted in biofilter soil-sand mixtures that had $50 \%$ biofilter soil and 50\% sand amendment and hand compaction test.

Table 10 shows example calculations how the above equation can be used. The test results indicated that the expected ranges of infiltration for the biofilter media-
Kesidual plots were inspected to determine it the error term in the regression model satisfies the four regression assumptions [22] (they must be independent, and have zero mean with a constant variance, and be normally distributed). To check the constant variance assumptions, the plots of residuals vs. the fitted values were inspected. 
To evaluate the normality of the residuals, normal probability plots and histograms of the residuals were also constructed. The Anderson-Darling test statistic was also calculated to check for normality. The normal probability plot of the residuals shown in Fig.11 shows that the fitted data are normally distributed (Anderson-Darling test for normality has a p-value greater than 0.05 , so the data are not significantly different from a normal distribution for the number of observations available). The zero mean of the residuals assumption was checked by examining the descriptive statistics and graphs of the residuals vs. fitted values and vs. the order of the observations. To determine if the residuals were independent of each other, graphs of the residuals vs. observation number were also examined.

The examination of the residual values vs. fitted values of the data indicated that there was a greater spread in the residuals for the higher fitted values. The model residual histogram was approximately bell shaped; the residuals were normally distributed and had zero mean, and were independent of each other. Model improvements should therefore focus on conditions that had high infiltration conditions. Fig. 12 shows the response surface plot for compaction and $\%$ sand vs. final infiltration rate using all of the column data. The highest infiltration rates were noted in biofilter media-sand mixtures that had the highest percentage of sand amendment and for hand compaction, as expected.

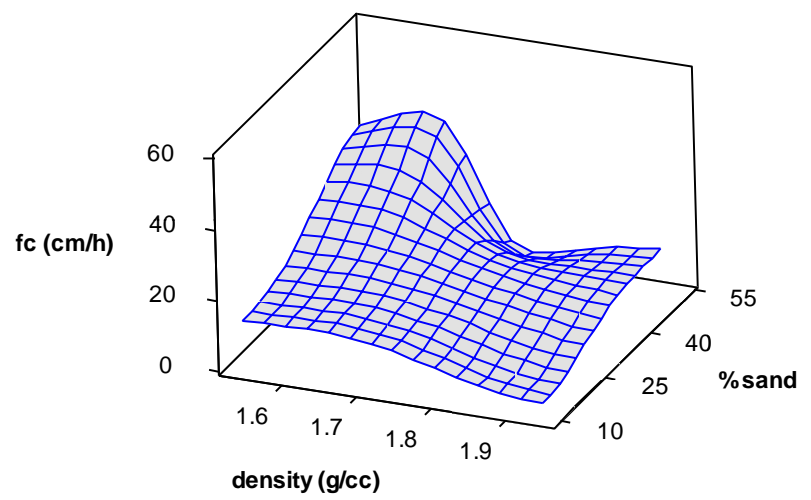

Fig. 12. Response surface plot for compaction and $\%$ sand vs. final infiltration rate

\section{K. Statistical Comparisons of Different Levels of Compaction}

The Kruskal-Wallis test includes multiple pairwise comparisons of groups to determine if at least one group is significantly different from the other groups being compared. This test compares the population medians of the groups, instead of the population means used by ANOVA and does not require normally distributed data. The Kruskal-Wallis method tests the hypothesis that all population medians are equal [23]. The multiple comparison tests were conducted using a MINITAB version 16 macro in a nonparametric setting [24]. Fig. 13 describes the significance of the differences for the saturated infiltration rates for different levels of compaction and using biofilter media only. Detailed statistical analyses are shown in reference [25]. The graph on the left of Fig. 13 displays box plots of groups with their sign confidence intervals for the medians. The graph on the right displays the non-absolute group mean rank standardized differences [24]. This latter plot shows the magnitude of the group differences and their directions. It also shows the positive and negative critical z-values and illustrates if a difference is likely statistically significant.

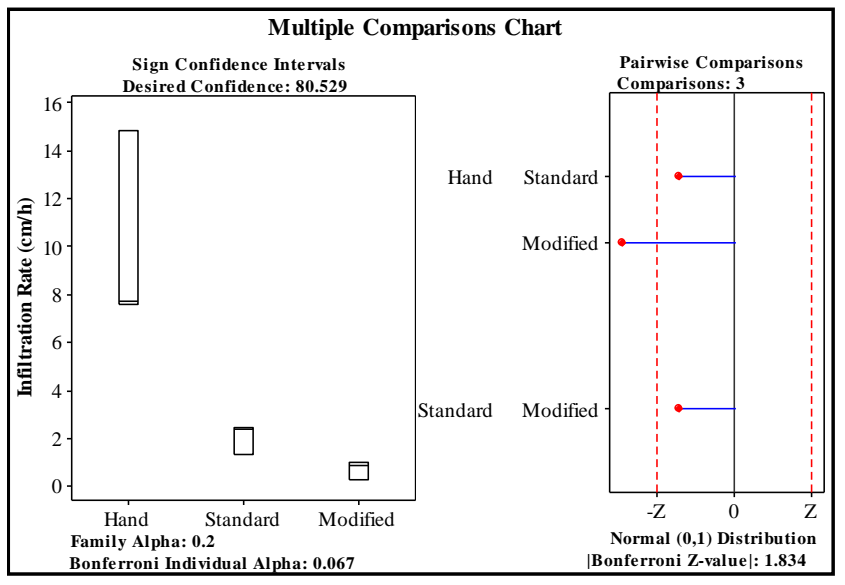

Fig. 9. Multiple comparison plots of laboratory infiltration measurements using biofilter media only

From Fig. 13, it is seen that the saturated infiltration rates for hand compaction are larger than the saturated infiltration rates using modified proctor compaction method, as expected. This difference is also shown to be statistically significant since the standardized difference distance goes beyond the critical $\mathrm{z}$-values compared to the other test groups. There are no significant differences noted between the saturated infiltration rate of the standard proctor and modified proctor compaction methods.

\section{IV.CONCLUSIONS}

The laboratory column test results indicated that the infiltration rates through all mixtures of biofilter media and filter sand are greater than the infiltration rates through the biofilter media alone for the three levels of compaction (hand compaction, standard proctor, and modified proctor). The column test results for the biofilter soil alone and with varying amounts of added peat, using the standard proctor compaction method, also indicated benefits by adding peat to the biofilter media material. Mixing the biofilter media with filter sand and peat improved the infiltration capacity of the media and also reduced the impact of compaction on the infiltration rates. The mixture containing $50 \%$ biofilter media and $50 \%$ filter sand the largest sand addition tested) exhibited the highest infiltration rates, as expected.

Peat amendments improve aeration and water holding capacity for plant roots, resulting in better growth. 
However, peat soils are more sensitive to compaction than other type of soils as they compress easily. Sand added to biofilter media generally improve drainage by lending by providing structural support to prevent compaction and fill large pore spaces without impairing drainage. It is important that stormwater practice designers determine the subsoil characteristics before designing stormwater treatment facilities and consider the use of added amendments (sand and peat) to the soils. The laboratory tests also demonstrated that soil compaction has dramatic effects on the infiltration rates; therefore, care needs to be taken during the construction of biofilter stormwater treatment facilities to reduce detrimental compaction effects. The infiltration values from the ponded locations are very small compared to the laboratory and field test infiltration values, indicating fully saturated media under moderately to severely compacted conditions. The compacted media column tests confirmed that the biofilter soils were compacted to a level between the Proctor and the modified Proctor levels, which resulted in similar infiltration rates as the in-situ measurements during actual rains.

In-situ infiltration measurements need to be evaluated carefully. The ponded water measurements in the biofilter were obtained after complete saturation by large rains. Also, ponding was not even throughout the biofilter, and water preferentially pooled in areas having depressions and with low infiltration capacities. Because they were in depressions, silting may have also occurred in those areas, further decreasing the infiltration rates. Long-term and continuous monitoring in a biofilter during rains is the best indication of performance, and these spot checks likely indicate the lowest values to occur. In fact, they were similar to the lowest infiltration rates observed with the small-scale infiltrometers and also corresponded to the compacted media column tests. Data from the infiltrometers also need to be cautiously evaluated as they also show very high rates that only occur during the initial portion of the event under unsaturated conditions. Most of the infiltration in biofilters likely occurs after saturated conditions and the lowest rates observed may be most representative of actual field conditions.

\section{REFERENCES}

[1] Virginia Department of Conservation and Recreation (VA DCR), "Stormwater Design Specification No. 8,"Infiltration Practices Version 1.7., 2010.

[2] R. E. Pitt, S-E. Chen, S. E. Clark, J. Swenson, and C.K. Ong, "Compaction's Impacts on Urban Storm-Water Infiltration," J. of Irri. and Drain. Eng., vol. 134(5), pp. 652-658, Oct. 2008.

[3] V.T. Chow, D.R. Maidment, and L.W. Mays, Applied Hydrology, New York, USA: McGraw-Hill, 1988.

[4] United States Department of Agriculture (USDA), Natural Resource Conservation Service (NRCS), Soil Quality Indicators, 2008

[5] J. Liu, D.J. Sample, C. Bell, and Y. Guan, "Review and research needs of bioretention used for the treatment of urban stormwater,' Water,vol. 6 (4), pp. 1069-1099, Apr. 2014

[6] R.J. Winston, J.D. Dorsey, and W.F. Hunt, "Monitoring the Performance of Bioretention and Permeable Pavement Stormwater Controls in Northern Ohio: Hydrology, Water Quality, Copyright to IARJSET and Maintenance Needs," Report to Chagrin River Watershed Partners, Inc., Aug., 2015.

[7] S.LeCoustumer, T.D. Fletcher, A. Deletic, and M. Potter, "Hydraulic Performance of Biofilter Systems for Stormwater management: lesson from a Field Study, ”Facility for Advancing water Biofiltration, Department of Civil Engineering, Institute for Sustainable water Resources, Monash University, Melbourne, Vic., 3800, Australia, 2008

[8] Pitt, R. and J. Voorhees. "SLAMM, the Source Loading and Management Model." In: Wet-Weather Flow in the Urban Watershed (Edited by Richard Field and Daniel Sullivan). CRC Press, Boca Raton. pp 103 - 139. 2002.

[9] Turf Tec International, Turf Tec instructions, Oakland Park, Florida, USA, 1989. Available: http://www.turftec.com/IN2lit.html

[10] J. Read, T. Wevill, T.D. Fletcher, and A. Deletic,"Variation among plant species in pollutant removal from stormwater in biofiltration systems," Water Research, vol. 42(4-5), pp. 893-902, Feb. 2008.

[11] C. H. Hsieh and A. P. Davis," Evaluation and optimization of bioretention media for treatment of urban stormwater runoff.," $\mathrm{J}$. Environ. Eng., vol. 131(11),pp. 1521-1531, Nov. 2005.

[12] C. Henderson, M. Greenway, I. Phillips,"Removal of dissolved nitrogen, phosphorus and carbon from stormwater by biofiltration mesocosms," Water Science and Technology, vol. 55 (4), pp. 183-191, Feb. 2007a.

[13] B.E. Hatt, T.D. Fletcher, and A. Deletic,"Hydrologic and pollutant removal performance of stormwater biofiltration systems at the field scale," J. Hydrol. Eng., vol. 365 (3-4), pp. 310-321, Feb. 2009

[14] C. Henderson, M. Greenway, and I. Phillips, "Sorption behaviour of nutrients in loamy-sand bioretention media subject to different conditions (vegetation, enrichment and incubation time),"in Proc.Rainwater and Urban Design Conference, 2007b, paper, Sydney, Australia, Aug., 2007b.

[15] K, Bratieres, T. D. Fletcher, A. Deletic, and Y. Zinger, "Nutrient and sediment removal by stormwater biofilters: A large-scale design optimisation study," Water Research, vol. 42 (14), pp. 3930-3940, Aug. 2008.

C. C. Mitchell and G. Huluka, Timely information agriculture \& natural resources, Agronomy and Soils Series. Alabama Cooperative Extension System, USA, 2011.

http://www.aces.edu/timelyinfo/Ag\%20Soil/2011/February/S-0211.pdf

[16] L.S. Sonon, U. Saha, and D.E. Kissel, Soil Salinity Testing, Data Interpretation and Recommendations, The University of Georgia Cooperative Extension. College of Agricultural and Environmental Sciences; College of Family and Consumer Sciences, USA, 2012.

[17] R. E. Pitt, Retrofit Stormwater Management Options: Performance and Relative Costs, Prepared for the City of Lincoln, Nebraska, USA, 2011.

[18] F.F. Munshower, Practical Handbook of Disturbed Land Revegetation.,Boca Raton, Florida, USA: Lewis Publishers, 1994.

[19] D. D. Carpenter and L. Hallam"Influence of Planting Soil Mix Characteristics on Bioretention Cell Design and Performance," J. Hydrol. Eng., vol. 15, pp. 404-416, 2010.

[20] G. E. P. Box, W. G. Hunter, and J. S. Hunter, Statistics for Experimenters, New York, USA: J Wiley, 1978.

[21] J. E. Matsonand B. R. Huguenard,'Evaluating Aptness of a Regression Model," Journal of Statistics Education, vol. 15, No.2.2007.

[22] J. D. Gibbons, Nonparametric Methods for Quantitative Analysis,3rd ed., Columbus,Ohio, USA: American Sciences Press, 1997.

[23] S. Orlich,Kruskal-Wallis Multiple Comparisons with a MINITAB Macro, Minitab,Inc., 2010.

[24] R.K. Sileshi, "Soil Physical Characteristics Related to Failure of Stormwater Biofiltration Devices," Ph.D. Dissertation, The University of Alabama, Tuscaloosa, Alabama, USA, Dec2013. 